\title{
Neonatal cannibalism in cage-bred wild rabbits (Oryctolagus cuniculus)
}

\author{
Canibalismo neonatal en conejos silvestres (Oryctolagus cuniculus) alojados en jaula \\ P González-Redondo ${ }^{\mathrm{a}^{*}}$, M Zamora-Lozano ${ }^{\mathrm{b}}$ \\ aUniversidad de Sevilla, Escuela Universitaria de Ingeniería Técnica Agrícola, \\ Departamento de Ciencias Agroforestales, 41013 Sevilla, Spain. \\ bUniversidad de Córdoba, Escuela Técnica Superior de Ingenieros Agrónomos y de Montes, \\ Departamento de Producción Animal, Campus de Rabanales, 14014 Córdoba, Spain.
}

\begin{abstract}
RESUMEN
El objetivo de este estudio fue analizar la práctica de canibalismo neonatal por conejas silvestres (Oryctolagus cuniculus) alojadas individualmente en jaulas ubicadas al aire libre. Se controló la incidencia de canibalismo en 98 partos producidos durante cinco años consecutivos por 19 conejas silvestres nacidas en jaula. Esta alteración de la conducta maternal, que estuvo limitada exclusivamente al periparto, tuvo una elevada incidencia (13,3\% de los partos) y estuvo asociada significativamente con una inadecuada conducta maternal, tal como la no introducción de pelo y paja en los nidales por parte de las conejas o los partos fuera del nidal. En el $84,6 \%$ de los partos en los que ocurrió canibalismo las conejas no introdujeron pelo en los nidales, y en el 92,3\% de los partos con gazapos canibalizados las conejas no introdujeron paja en los nidales. El canibalismo también estuvo asociado con una gran proporción de conejas que parían fuera de los nidales $(53,8 \%)$. Se discute que el canibalismo practicado por las conejas silvestres alojadas en jaula es una manifestación del fracaso en el desarrollo de la conducta maternal como consecuencia del estrés que experimentan en cautividad.
\end{abstract}

Key words: cannibalism, maternal behaviour, Oryctolagus cuniculus, wild rabbit.

Palabras clave: canibalismo, comportamiento maternal, Oryctolagus cuniculus, conejo silvestre.

\section{INTRODUCTION}

Semi-intensive breeding of wild rabbits (Oryctolagus cuniculus) intended for game restocking is widespread in many countries (Arthur 1989, González-Redondo 2001). In contrast, the intensive breeding of wild rabbits in cages, which is on the rise, is rather difficult and unproductive (Assheton 1910, Parer et al 1987, González-Redondo 2003). This is principally due to the reduced proportion of rabbits that give birth (Ward 1971, Adams 1975, González-Redondo 2003) and to the failure of maternal behaviour during the peripartum (González-Redondo 2003), resulting in a small number of nursing and weaned kits from each female that gives birth (Parer et al 1987, González-Redondo 2003).

The development of the maternal behaviour complex in the peripartum period has been well studied in both the wild rabbit in the wild (Lloyd and McCowan 1968, Gibb 1993) and in domestic breeds bred in captivity (Ross et al 1956 , Venge 1963). This behaviour complex is hormonallycontrolled (González-Mariscal 2001) and comprises the introduction of nesting materials (dry vegetable matter)

Accepted: 02.04.2008.

* Universidad de Sevilla, Escuela Universitaria de Ingeniería Técnica Agrícola, Departamento de Ciencias Agroforestales, Carretera de Utrera km 1, 41013 Sevilla, Spain; pedro@us.es into the burrow previously dug by the wild doe (Lloyd and McCowan 1968, Gibb 1993). In domestic rabbit farming the nest box is filled with straw or wood chips by the farmer (Ross et al 1956). The doe plucks hair from her belly and uses it to line the nest (Ross et al 1956, Lloyd and McCowan 1968). Does give birth within the nest box or burrow (Lloyd and McCowan 1968, Gibb 1993) and nurse the kits usually once a day (Venge 1963, Lloyd and McCowan 1968).

In the rabbit, maternal behaviour and reproductive success are often impaired by the stress originating from the keeping system and handling, and lead to alterations in the nest-making behaviour and kits losses (Cruz and Beyer 1972, Harkness and Wagner 1989, Emeash and Karousa 1994, Easson 2001, Baumann et al 2005). An adequate development of maternal behaviour during peripartum is characterised, among other factors, by the absence or reduced incidence of disorders such as cannibalism, which is defined as the doe's consumption of all or part of the body of at least one neonate from her litter (Denenberg et al 1960). The extent of cannibalism (Sawin and Crary 1954, Delaveau 1979, Leone-Singer and Hoop 2003) as well as its causing factors (Sawin and Crary 1954, Denenberg et al 1960, Leone-Singer and Hoop 2003) in the domestic rabbit are well known, yet cannibalism practiced by wild rabbits bred in captivity has never been studied. This article analyses the practice of cannibalism by wild rabbit does born, raised and bred in cages. 


\section{MATERIAL AND METHODS}

The data used came from 98 parturitions and were gathered from 19 female cage-born wild rabbits during five consecutive years. The does were individually housed in wire mesh cages $\left(38 \times 51 \times 35 \mathrm{~cm}^{3}\right)$, similar to those used in meat rabbit farming, that were placed outdoors at an experimental farm located in the same region where the initial stock of rabbits were caught. Each cage was equipped with a wooden nest box, consisting of a closed internal chamber $\left(17 \times 23 \times 20 \mathrm{~cm}^{3}\right)$ that was accessed by a tunnel with a cross section of $9 \times 8 \mathrm{~cm}^{2}$. A plastic tray $\left(16 \times 22 \times 11 \mathrm{~cm}^{3}\right)$ was placed within the nest box chamber in which the does could prepare the nest, give birth and nurse the kits (González-Redondo 2006).

The does mated in the bucks' cages, in which they remained seven days, at the conclusion of which they were returned to their own cages. From this moment on, the does had access to the nest box so that they could also use it as shelter, with the purpose of reducing stress, since it is known that captive wild rabbits spend a large part of the diurnal period in the interior of the nest boxes if they have them at their disposal (Selzer and Hoy 2003). Three days before the anticipated due date the does were provided with cereal straw, scattered on the floor of the cage, so that they could make the nest. The weaning of the kits took place 30 days after parturition. The female rabbits were re-mated either the same day as the weaning when they had nursed a litter, the day after parturition when all of the litter died in the peripartum period, or 35 days after the previous mating when they didn't give birth.

The does received water ad libitum and were fed $a d$ libitum with commercial feed for breeding meat rabbits. Analytical constituents of the feed consumed by the does were $16.5 \%$ crude protein, $16.5 \%$ crude fibre, $3.5 \%$ crude fat, $9.7 \%$ ash, $1.2 \%$ calcium, $0.5 \%$ phosphorus, $13.5 \%$ starch, $0.52 \%$ methionine+cysteine, and 0.96 arginine. This feed contributed 2,340 kcal of DE/kg DM.

For each parturition the following data were recorded: the previous experience of the doe (primiparous or multiparous), the presence of straw in the nest box, the presence of hair in the nest box, the total litter size at parturition, the number of kits born alive (that is, those that survived the peripartum period), the occurrence of cannibalism (some or all kits cannibalised, or no kits cannibalised), the place of parturition (inside or outside the nest box), and the age of the doe at the time of parturition. Peripartum period comprised first 24 hours after parturition. Nest boxes were carefully checked twice daily in order to confirm the occurrence of parturition and to monitor litter status.

\section{STATISTICAL ANALYSIS}

In order to analyse the relation between occurrence of cannibalism and the variables age of the female, total litter size at parturition and number of kits born alive, Student's $t$ tests were used. In order to analyse the relation between occurrence of cannibalism and the variables previous experience of the doe, place of parturition, presence of straw in the nest box, and presence of hair in the nest box, Chi-square tests were used. The statistical analyses were performed using the program SPSS 9.0 for Windows (SPSS Inc. 1999).

\section{RESULTS AND DISCUSSION}

This is the first investigation that describes the practice of neonatal cannibalism by cage-bred wild rabbit does. We found that in $13.3 \%$ of the litters either all kits $(n=$ $10,10.2 \%)$ or some kits $(n=3,3.1 \%)$ were cannibalised (table 1). The cannibalism rate that we observed was in the range observed by Sawin and Crary (1954) in domestic rabbits, which is 8 to 15 percent of litters. However, it was much higher than that recorded by Leone-Singer and Hoop (2003) in Swiss farms, in which only $0.5 \%$ of the kits were lost up to 14 days old for this reason. It was also much higher than the incidence recorded by Partridge et al (1981), who observed that cannibalism leads to the loss of approximately $4 \%$ of the kits postpartum in domestic rabbits. Cannibalism is a phenomenon that normally occurs in meat rabbits (Sawin and Crary 1954), just as much in intensive (Lukefahr et al 2004) as in traditional cuniculture (Bergaoui 1992). DeSantis and Schmaltz (2004) point out that it is also common in rodents. However, it is considered atypical behaviour, even in captivity, in the wild cottontail rabbit (Sylvilagus floridanus) (Smith 1974). Therefore, the practice of cannibalism by cage-bred wild rabbit does of our study turned out to be a common practice and can be considered, in general, higher than that of domestic does, in which it is accepted that they have a low incidence (Sawin and Crary 1954, Harkness and Wagner 1989), because the proportion of pre-weaning mortality in domestic kits that can be attributed to cannibalism ranges between 15\% (Partridge et al 1981) and 18\% (Delaveau 1979). Differences in the incidence of cannibalism among the breeds of domestic rabbits have been described (Denenberg et al 1960). The genetic differences between the wild rabbit and the domestic breeds (Branco et al 2000) can partly explain the high incidence of cannibalism that we observed in wild cage-bred rabbits. These genetic differences predispose the animals to react differently to the handling and environment in captivity, resulting in a different incidence of cannibalism.

The intensity of cannibalism the wild rabbits of our experiment practiced was variable, ranging from some kits having only their ears, tail or extremities eaten, to others having the large part of their bodies devoured by the doe. Its intensity was similar to that described in domestic breeds (Hafez et al 1966, Cruz and Beyer 1972) and in wild cottontail rabbits in captivity (Smith 1974).

In the wild female rabbits of this experiment no differences in the occurrence of cannibalism were found 
Table 1. Contingency table of the relation between the occurrence of cannibalism in wild rabbits and the variables: previous experience, place of parturition, presence of hair in nest box, and presence of straw in nest box. Values expressed as $n(\%)$.

Tabla de contingencia de relación entre la ocurrencia de canibalismo en conejos silvestres y las variables experiencia previa, lugar de parto, presencia de pelo en el nidal y presencia de paja en el nidal. Valores expresados como $n(\%)$.

\begin{tabular}{|c|c|c|c|c|c|}
\hline Previous experience $(\mathrm{P}>0.05)^{1}$ & \multicolumn{2}{|c|}{$\begin{array}{c}\text { No kits } \\
\text { cannibalised }\end{array}$} & $\begin{array}{l}\text { Some or all kits } \\
\text { cannibalised }\end{array}$ & \multicolumn{2}{|c|}{ Total } \\
\hline Primiparous & 17 & (20.0) & $2 \quad(15.4)$ & 19 & (19.4) \\
\hline Multiparous & 68 & $(80.0)$ & $11 \quad(84.6)$ & 79 & (80.6) \\
\hline \multicolumn{6}{|l|}{ Place of parturition $(\mathrm{P}<0.01)^{1}$} \\
\hline All kits inside nest box & 73 & (85.9) & $6 \quad(46.2)$ & 79 & (80.6) \\
\hline Some or all kits outside nest box & 12 & $(41.1)$ & $7 \quad(53.8)$ & 19 & (19.4) \\
\hline \multicolumn{6}{|c|}{ Presence of straw in the nest box $(\mathrm{P}<0.01)^{2}$} \\
\hline With straw & 57 & $(67.1)$ & $1 \quad(7.7)$ & 58 & $(59.2)$ \\
\hline Without straw & 28 & (32.9) & $12 \quad(92.3)$ & 40 & $(40.8)$ \\
\hline \multicolumn{6}{|c|}{ Presence of hair in the nest box $(\mathrm{P}<0.01)^{1}$} \\
\hline With hair & 68 & $(80.0)$ & $(15.4)$ & 70 & (71.4) \\
\hline \multirow[t]{2}{*}{ Without hair } & 17 & $(20.0)$ & $11 \quad(84.6)$ & 28 & (28.6) \\
\hline & 85 & $(86.7)$ & $(13.3)$ & 98 & $(100.0)$ \\
\hline
\end{tabular}

between primiparous and multiparous females (table 1), coinciding with other authors' observations that do not find parturition order to have any influence in domestic rabbits (Denenberg et al 1960, Hafez et al 1966). Nevertheless, cannibalism in domestic breeds has been described to be more frequent in hyper-excitable or stressed primiparous rabbits (Cruz and Beyer 1972, Harkness and Wagner 1989, Easson 2001), to the extent that half of cannibalism is practiced by primiparous females (Delaevau 1979). It is likely that in our case the level of stress experienced by the rabbits, that probably was very high due to the fact that they were wild animals, equally affected both primiparous and multiparous rabbits, resulting in similar levels of cannibalism in both groups of rabbits.

Although neonatal mortality in domestic breeds is greater when the doe gives birth at a young age (Delaveau 1979), in the wild rabbits of our experiment we did not observe that the age of the female influenced the occurrence of cannibalism (table 2), most likely because the minimum age at which they were first mated (at least six months) was significantly higher than the typical age at which meat rabbit does are first mated (4.5 months; Lebas et al 1996).

Neonatal cannibalism practiced by the wild rabbits in our experiment was clearly associated with other maternal behaviours. In particular, the lining of the nest with hair that the does pull out from their abdominal region just before parturition is one of the components characteristic of the maternal behaviour complex of the species (Ross et al 1956, Lloyd and McCowan 1968). In our study there was a highly significant incidence of cannibalism when the rabbits did not introduce hair into the nest box (table 1). This association between cannibalism and poor nest quality, measured in terms of the quantity of hair with which it is lined, has also been observed in domestic rabbits (Sawin and Crary 1954, Denenberg et al 1960, Cruz and Beyer 1972) and in wild cottontail rabbits kept in captivity (Smith 1974). It is a secondary manifestation of the failure of maternal behaviour in parturition most likely influenced by environmental factors (Sawin and Crary 1954) or of the handling that, as in other causes of neonatal mortality associated with poor nest quality, is due to the response of the mother (Delaveau 1979). This argument is confirmed by Cruz and Beyer (1972), which verifies that lesions on the medial part of the septum cause, in a high proportion of domestic rabbits, the incidence of cannibalism associated in most cases with the absence of nest construction and with the absence of hair in its lining. This is due to the fact that the septum is a forebrain structure that is rich in oestrogen receptor- $\alpha$-inmunoreactive neurons, known to be involved in the control of the reproductive function (González-Mariscal 2001). In the wild rabbits of our experiment the stress originating from captivity can lower or alter the level of control in maternal behaviour dependent on the nervous and endocrine systems, resulting in a high rate of cannibalism. On the other hand, we also observed a greater incidence of cannibalism when the does did not introduce straw into the nest boxes (table 1). The stratum of straw is 
Table 2. Descriptive statistics of the quantitative variables related to wild rabbit parturitions $(n=98)$ in cages (Mean \pm SD). Estadísticos descriptivos de las variables cuantitativas relacionadas con los partos $(n=98)$ de las conejas silvestres (Media \pm DT).

\begin{tabular}{lccc}
\hline Variable & No kits cannibalised & Some or all kits cannibalised & Total \\
\hline Age of female, years $(\mathrm{P}>0.05)$ & $2.24 \pm 1.22$ & $2.00 \pm 0.82$ & $2.20 \pm 1.18$ \\
Total litter size at parturition $(\mathrm{P}<0.05)$ & $3.36 \pm 1.20$ & $2.62 \pm 1.19$ & $3.27 \pm 1.22$ \\
Kits born alive $(\mathrm{P}<0.01)$ & $2.79 \pm 1.61$ & $0.85 \pm 1.35$ & $2.53 \pm 1.71$ \\
\hline
\end{tabular}

another one of the nest's components that is made by the does (Ross et al 1956, Lloyd and McCowan 1968, Gibb 1993). Given that the does voluntarily introduced straw into the nest boxes just before parturition, its absence in the nest boxes also revealed an inadequate development of nest-making behaviour. In part, the adequate addition of straw could reduce the rabbits' stress and the stressinduced alterations in maternal behaviour, among which cannibalism is found, thus correcting them (Emeash and Karousa 1994). Also in sows it has been found that the difficulty of carrying out the nesting behavior may cause stress and alterations in the maternal behaviour (Jarvis et al 2001), and that the clearest instance of adverse maternal behaviour is infanticide or savaging of newborn piglets (Edwards 2002).

The occurrence of cannibalism was significantly associated with the parturition of some or all of the litter outside the nest box (table 1). This same association has been found in domestic rabbits (Sawin and Crary 1954, Denenberg et al 1960, Cruz and Beyer 1972). Both behaviours are also a secondary manifestation of abnormal maternal behaviour generalized and probably influenced more by environmental factors prevalent at the time than by causes inherent to the doe (Sawin and Crary 1954). The design of the nest box has a great importance on the survival of the kits, given that it is necessary for the doe to build a nest to give birth in and adequately nurse her litter (Lebas et al 1996). The design of the nest box that we used turned out to be effective because it faithfully imitates the structure of a breeding burrow, consisting of a chamber of reduced volume, which is accessed from a narrow entry tunnel (González-Redondo 2006). However, it is possible that the incidence of cannibalism would have decreased if the entry tunnel of the nest box had been designed with a door flap that left the entrance closed, similar to how rabbits make a breeding burrow (Lloyd and McCowan 1968). In fact, we observed how some rabbits plugged the access tunnel of the nest box using the straw they had at their disposal. In effect, Baumann et al (2005) found that domestic rabbits suffer more stress when they cannot cover the entrance of the nest box and that the placement of a door flap in the entrance of the nest box reduces the mortality of nursing kits by eliminating the behavioural conflict shown in the does that are provided with open nest boxes, whose entrance they try to close.
Neonatal cannibalism by wild rabbit does housed in cages is probably an indicator of the stressful environment or housing, as is suggested by Emeash and Karousa (1994) in domestic female rabbits, and by Smith (1974) in cottontail rabbits kept in captivity. An excessive concentration of animals has also been described as a cause of cannibalism in both domestic rabbits (Easson 2001) and group-housed wild cottontail rabbits (Smith 1974). This propensity towards cannibalism comes not as much from the lack of available space for the doe as from the change in social relationships (Smith 1974) among the individuals of colonies when the number of rabbits exceeds a certain limit. In our case, given that the does were housed individually, this type of stress was not a cause of cannibalism. However, it is possible that the reduced surface area of the cages that were used, between 25 and 50 percent smaller than those normally used in industrial cuniculture (Lebas et al 1996), had caused considerable stress to the does of the experiment which, being wild and therefore more reactive than domestic rabbits (Assheton 1910, González-Redondo 2003), usually suffer more intensely when they are kept in strict confinement. In fact, the does sought permanent shelter in the nest boxes, behaviour also described by Assheton (1910) who never saw wild rabbits housed in cages come outside of their shelters. It has been stated that housing conditions influence the incidence of cannibalism in domestic rabbits, making it greater in rabbits housed in lower-level cages compared with those housed in upper levels, an effect that Emeash and Karousa (1994) attribute to long-term stressful conditions, which present with high levels of corticosterone. In our case, it is likely that the environmental differences between the cage housing conditions and the natural environment produced high levels of stress in the wild rabbits, and consequently, the high rate of cannibalism that we observed.

The high incidence of cannibalism as a consequence of stressful handling situations is confirmed by the observation that frequent abdominal palpations increase the rate of cannibalism (Araki et al 2000). In rabbits used as recipients of oocytes for the production of transgenic rabbits, there is a frequent emergence of neonatal cannibalism as a consequence of the stressful handling to which they are subjected (Marian et al 1999, Araki et al 2000). Other situations that involve changes to the physiological state of the rabbit, like lesions in the septum, increase the occur- 
rence of cannibalism to as much as one third of primiparous rabbits in domestic breeds (Cruz and Beyer 1972).

In $77 \%$ of the cases in which cannibalism occurred it affected all kits of the litter. This coincides with the observations of Delaveau (1979), which found that the causes of mortality in domestic rabbits are identical for all kits of the same parturition. This suggests that this type of neonatal mortality is dependent upon the behaviour of the doe, which is uniformly practiced upon the whole litter in most occasions, and is relatively independent of the state of each kit. If the does only practiced cannibalism on the kits that presented some characteristic or defect that led the female to aggress them, the proportion of litters in which only some kits are cannibalised would be greater. In fact, although in our case no necropsies were performed on the dead kits, upon visual inspection they did not appear to suffer from any diseases or defects, nor did they appear to be debilitated.

In our study, all episodes of cannibalism occurred in the peripartum period, observing no cases in the days following parturition, suggesting that it was a result of an alteration in behaviour strictly confined to the perinatal period and, therefore, associated with the failure of maternal behavioural development. This coincides with observations in domestic rabbits, in which the does eat only those kits that are dead but still warm (Rashwan and Marai 2000); that is, that the females cannibalise primarily in the peripartum period. This also coincides with the observations of Cruz and Beyer (1972), which state that most cases of cannibalism occur during the first 48 hours post parturition. Smith (1974) also observes that cannibalism in cottontail rabbits kept in captivity occurs soon after parturition. In fact, there are few cases in which does cannibalise older nursing kits (Hafez et al 1966, Cruz and Beyer 1972) and, in general, three-fourths of kit mortality prior to weaning occurs in the first seven days post parturition (Partridge et al 1981). Furthermore, perinatal cannibalism is dependent upon the alteration in the doe's behaviour, as is confirmed by the observation of Hafez et al (1966), who in their experiment kill the kits in the first hour post parturition and verify that the mothers do not cannibalise them, suggesting that if the doe does not undergo alterations in maternal behaviour she does not practice cannibalism regardless of the state of the kits. In fact, De Franceschi (1983) indicates that does can cannibalise perfectly normal kits. The association of cannibalism with the failure of the maternal behaviour complex in the doe would be supported by the observation of Leone-Singer and Hoop (2003), who attribute this type of mortality to insufficient nursing by the mother.

Cannibalism turned out to be negatively associated with total litter size at parturition (table 2). Our observation contradicted that described in domestic breeds, in which the incidence of cannibalism and other types of mortality of nursing kits increase with the size of the litter (Delaveau 1979, Rashwan and Marai 2000). This difference in behaviour between wild and domestic rabbits could be due to the great difference in the total litter size at parturition between both genetic types, which in captive wild rabbits is on average 3.3 kits born total, with a maximum of 6 (González-Redondo 2003), while in meat breeds it is on average 8 kits born total, with a maximum that can exceed 12 kits (Lebas et al 1996). In the wild rabbits of our experiment a large number of kits could stimulate a better development of maternal behaviour, whereas the genetic selection used in meat breeds in order to increase the litter size (Lebas et al 1996) can lead to excessive litter sizes, reducing the individual weight and viability of the kits (Estany et al 1986). In fact, unlike domestic rabbits, wild rabbits show no significant reduction in birth weight with increased litter size (Boyd 1985).

Some authors have affirmed that cannibalism can be associated with a diet low in energy (Harkness and Warner 1989); whereas Hafez et al (1966) do not find that caloric intake affects cannibalism in domestic rabbits. In our case the energy contribution was adequate for domestic breeding rabbits (Lebas et al 1996, De Blas and Wiseman 1998), thus the cases of cannibalism that we recorded should not be due to an energy deficiency in the diet. It has also been described that cannibalism frequently occurs in rabbits subjected to a low level of nutrition (Hafez et al 1966). This was not the case in our rabbits as they were fed $a d$ libitum, thereby making it not a causing factor. The lack of fibre has also been suggested as one of the causes of cannibalism during the peripartum period (Emeash and Karousa 1994). In our case it's unlikely that the feed administered to the rabbits was low in fibre since it had been formulated in order to meet the needs of breeding rabbits (Lebas et al 1996, De Blas and Wiseman 1998). In addition, the straw supplied to line the nest might have satisfied a hypothetical deficit, due to its richness in crude fibre (Emeash and Karousa 1994, De Blas and Wiseman 1998). Although nutritional imbalances and deficiencies have been described as factors causing cannibalism in rabbits (Hafez et al 1966, Harkness and Wagner 1989), it is unlikely that in our case it had a nutritional origin. The feed that we used, which is a classic make for domestic breeding rabbits (Lebas et al 1996, De Blas and Wiseman 1998), besides being a complete and balanced food, was very similar in composition to the diet consumed by wild rabbits during the breeding period of a free population located in a region (Serrano 2006) very geographically close to that of origin of the parents of the rabbits in our experiment. It is unlikely that feeding wild rabbits in captivity with feed for domestic rabbits caused deficiencies in them that could be the cause of cannibalism. In fact, there are numerous experiments in which wild rabbits fed with feed for domestic rabbits have successfully lived and bred in captivity (Ward 1971, Parer et al 1987, González-Redondo 2003). The insufficient availability of drinking water in the peripartum period has been described as a common cause of neonatal cannibalism in rabbits (Bergaoui 1992, Rashwan and Marai 2000). However, in 
our experiment this was not the cause of this alteration in maternal behaviour because the does were provided with water ad libitum.

In conclusion, neonatal cannibalism practiced by cage-bred wild rabbits seemed to originate from the stress caused by the housing environment and their handling in captivity, particularly felt due to their being wild animals, and manifested itself as a form of the failure of maternal behaviour during the postpartum period, associated with disorders such as not using straw or hair in nest-building or giving birth outside the nest box. Although other interpretations are possible and more research based on the measure of stress indicators is needed, this could coincide with the link between stress, measured as stress-induced hyperthermia, and cannibalism described in silver foxes under commercial fur farming conditions (Bakken et al 1999). The reduction of the incidence of cannibalism, as a way to increase the productivity of farms that produce rabbits for game restocking, requires the design of cages and nest boxes and the implementation of handling programs consistent with the ethological demands of the wild rabbit.

\section{SUMMARY}

The aim of this study was to analyse the occurrence of neonatal cannibalism by individually outdoors cage-bred wild rabbit does (Oryctolagus cuniculus). Ninety eight parturitions that were gathered from 19 female cage-born wild rabbits during five consecutive years were monitored for cannibalism incidence. This alteration in maternal behaviour, which was exclusively limited to the peripartum period, had a high incidence ( $13.3 \%$ of parturitions) and was significantly associated with inadequate maternal behaviour such as not using straw or hair in nestbuilding or giving birth outside the nest box. In $84.6 \%$ of the parturitions with occurrence of cannibalism the does did not introduce hair into the nest boxes, and in $92.3 \%$ of the parturitions with cannibalised kits the does did not introduce straw into the nest boxes. Cannibalism was also associated with a large proportion of rabbits that gave birth outside the nest boxes (53.8\%). It is discussed that cannibalism practiced by wild rabbit does in captivity is a manifestation of the failure of maternal behaviour, a consequence of the stress they experience in captivity.

\section{REFERENCES}

Adams CE. 1975. Stimulation of reproduction in captivity of the wild rabbit, Oryctolagus cuniculus. J Reprod Fertil 43, 97-102.

Araki M, J Fan, M Challah, A Bensadoun, N Yamada, K Honda, $\mathrm{T}$ Watanabe. 2000. Transgenic rabbits expressing human lipoprotein lipase. Cytotechnology 33, 93-99.

Arthur CP. 1989. Les opérations de repeuplement hivernal en lapins de garenne. Bull Mens ONC 139, 15-28.

Assheton R. 1910. Variation and Mendel. Some observations on the crossing of wild rabbits with certain tame breeds. Guys Hosp Rep 64, 313-342.

Bakken M, RO Moe, AJ Smith, GME Selle. 1999. Effects of environmental stressors on deep body temperature and activity levels in silver fox vixens (Vulpes vulpes). Appl Anim Behav Sci 64, 141-151.

Baumann P, H Oester, M Stauffacher. 2005. The use of a cat-flap at the nest entrance to mimic natural conditions in the breeding of fattening rabbits (Oryctolagus cuniculus). Anim Welfare 14, 135-142.
Bergaoui R. 1992. L'élevage du lapin en Tunisie peut contribuer à résoudre le problème de déficit en viande du pays. Options Méditerranéennes, Série Séminaires 17, 23-32.

Boyd IL. 1985. Investment in growth by pregnant wild rabbits in relation to litter size and sex of the offspring. J Anim Ecol 54, 137-147.

Branco M, N Ferrand, M Monnerot. 2000. Phylogeography of the European rabbit (Oryctolagus cuniculus) in the Iberian Peninsula inferred from RFLP analysis of the cytochrome $\mathrm{b}$ gene. Heredity $85,307-317$.

Cruz ML, C Beyer. 1972. Effects of septal lesions on maternal behavior and lactation in the rabbit. Physiol Behav 9, 361-365.

De Blas C, J Wiseman. 1998. The nutrition of the rabbit. CAB International, Wallingford, UK.

De Franceschi D. 1983. Mortalità dalla nascita allo svezzamento. Riv Coniglicoltura 20, 18-21.

Delaveau A. 1979. Mortalité des lapereaux au nid. Ann Zootech 28 , 165-172.

Denenberg VH, SF Petropolus, PB Sawin, S Ross. 1960. Genetic, physiological, and behavioral background of reproduction in the rabbit: VI. Maternal behavior with reference to scattered and cannibalized newborn and mortality. Behaviour 15, 71-76.

DeSantis DT, LW Schmaltz. 2004. The mother-litter relationship in developmental rat studies: Cannibalism vs caring. Dev Psychobiol 17, 255-262.

Easson W. 2001. A review of rabbit and rodent production medicine. Seminars in Avian and Exotic Pet Medicine 10, 131-139.

Edwards SA. 2002. Perinatal mortality in the pig: environmental or physiological solutions? Livest Prod Sci 78, 3-12.

Emeash HH, MM Karousa. 1994. The influence of some managemental programmes on maternal anomalies and pup's performance in White New Zealand rabbits. In: Baselga M, Marai IFM (eds). Rabbit production in hot climates. CIHEAM-IAMZ, Zaragoza. Cahiers Options Méditerranéennes 8, 425-429.

Estany J, S Balasch, M Pla. 1986. Estudio de la viabilidad de los gazapos durante la lactación según un modelo de regresión logística. ITEA Producción Animal 62, 23-32.

Gibb JA. 1993. Sociality, time and space in a sparse population of rabbits (Oryctolagus cuniculus). J Zool 229, 581-607.

González-Mariscal G. 2001. Neuroendocrinology of maternal behavior in the rabbit. Horm Behav 40, 125-132.

González-Redondo P. 2001. Producción de conejos de monte en cautividad. Revista Forestal Española 27, 4-11.

González-Redondo P. 2003. Contribución al conocimiento de la producción del conejo silvestre (Oryctolagus cuniculus) en cautividad estricta. Tesis de Doctorado, Universidad de Córdoba, Córdoba, España.

González-Redondo P. 2006. Proposal of a nest box for the reproduction of wild rabbits (Oryctolagus cuniculus) in cages. World Rabbit Sci $14,115-121$.

Hafez ESE, DR Lindsay, LA Moustafa. 1966. Some factors affecting nest building in the domestic rabbit. Z Tierpsychol 23, 691-700.

Harkness JE, JE Wagner. 1980. Biología y clínica de conejos y roedores. Acribia, Zaragoza, España.

Jarvis S, BJ Van der Vegt, AB Lawrence, KA McLean, LA Deans, J Chirnside, SK Kalvert. 2001. The effect of parity and environmental restriction on behavioural and physiological responses of pre-parturient pigs. Appl Anim Behav Sci 71, 203-216.

Lebas F, P Coudert, H De Rochambeau, RG Thébault. 1996. El conejo. Cría y patología. FAO, Roma, Italia.

Leone-Singer A, R Hoop. 2003. Untersuchung zur Säuglingsmortalität bei Mastkaninchen in der Schweiz. Schweizer Arch Tierheilkd 145, 329-335.

Lloyd HG, D McCowan. 1968. Some observations on the breeding burrows of the wild rabbits Oryctolagus cuniculus on the island of Skokholm. J Zool 156, 540-549. 
Lukefahr SD, PR Cheeke, JI McNitt, NM Patton. 2004. Limitations of intensive meat rabbit production in North America: A review. Can J Anim Sci 84, 349-360.

Marian AJ, Y Wu, D-S Lim, M McCluggage, K Youker, Q-T Yu, R Brugada, F DeMayo, M Quinones, R Roberts. 1999. A transgenic rabbit model for human hypertrophic cardiomyopathy. J Clin Invest 104, 1683-1692.

Parer I, WR Sobey, D Conolly. 1987. Reproduction of the wild rabbit (Oryctolagus cuniculus) under varying degrees of confinement. CSIRO, Aust. Division of Wildlife and Rangelands Research Technical Paper 36, 1-12.

Partridge GG, S Foley, W Corrigall. 1981. Reproductive performance in purebred and crossbred commercial rabbits. Anim Prod 32, 325-331.

Rashwan AA, IFM Marai. 2000. Mortality in young rabbits: A review. World Rabbit Sci 8, 111-124.

Ross S, VH Denenberg, PB Sawin, P Meyer. 1956. Changes in nest-building behaviour in multiparous rabbits. Brit J Anim Behav 4, 69-74.
Sawin PB, DD Crary. 1954. Genetic and physiological background of reproduction in the rabbit: II. Some racial differences in the pattern of maternal behavior. Behaviour 6, 128-146.

Selzer D, S Hoy. 2003. Comparative investigations on behaviour of wild and domestic rabbits in the nestbox. World Rabbit Sci 11, 13-21.

Serrano S. 2006. Eficacia de la gestión del conejo silvestre (Oryctolagus cuniculus) en Extremadura. Análisis de los principales factores ambientales de recuperación: refugio y alimento. Tesis de Doctorado, Universidad de Extremadura, Cáceres, España.

Smith RJ. 1974. Cannibalism by confined cottontail rabbits. J Wildlife Manage 38, 576-578.

SPSS Inc. 1999. SPSS 9.0. Manual del Usuario. SPSS Inc., Chicago, Estados Unidos.

Venge O. 1963. The influence of nursing behaviour and milk production on early growth in rabbits. Anim Behav 11, 500-506.

Ward CP. 1971. Gestation periods and body weights of wild rabbits (Oryctolagus cuniculus) in captivity. New Zealand J Sci 14, 10-17. 
